Pomáhajúce profesie, roč. 3, č. 2, 2020, 23-32

\title{
REZILIENCIA A ŤAŽKOSTI S KARIÉROVÝM ROZHODOVANÍM ŠTUDENTOV PRED DRUHOU SMEROVOU VOL'BOU
}

\author{
Katarína Baňasová ${ }^{1}$, Veronika Vrábl'ová ${ }^{2}$ \\ ${ }^{1}$ Ústav aplikovanej psychológie FSVaZ UKF Nitra \\ ${ }^{2}$ Katedra psychologických vied FSVaZ UKF Nitra \\ kbanasova@ukf.sk
}

\begin{abstract}
Abstrakt: Ciel'om predkladanej práce bolo identifikovat' vzt'ah medzi rezilienciou a t’ažkost’ami s kariérovým rozhodovaním u stredoškolských študentov. Naša výskumná vzorka pozostávala zo 111 participantov (47 mužov a 64 žien) dvoch slovenských gymnázií, konkrétne študentov 4. ročníka vo veku 18-19 rokov. Miera reziliencie bola zist'ovaná prostredníctvom Škály reziliencie (Wagnild, Young, 1993) a na zistenie jednotlivých t'ažkostí s kariérovým rozhodovaním sme použili dotazník EPCD (Emotional and Personality Career Difficulties Scale), pochádzajúci od izraelských autorov Sakaovej, Gatiho a Kellyho (2008). Výsledky preukázali štatisticky významný negatívny vzt'ah medzi rezilienciou a t’ažkost’ami s kariérovým rozhodovaním. Reziliencia negatívne korelovala so všetkými troma dimenziami t'ažkostí v kariérovom rozhodovaní - Pesimistický pohl'ad, Úzkost', Sebaobraz a identita. Zistenia môžu byt' prínosné pre d'alšie skúmanie v oblasti kariérového poradenstva.
\end{abstract}

Klúčové slová: reziliencia, t’ažkosti s kariérovým rozhodovaním, stredoškolskí študenti, druhá smerová vol'ba

\section{1 ÚVOD}

Svet práce podlieha v posledných rokoch dramatickým zmenám. Na trhu sa nepretržite objavujú nové profesie, o ktoré mladá generácia prejavuje záujem vo väčšej miere ako o tradičné povolania, ktoré sa pomaly vytrácajú. Skúmajú sa teórie rozhodovania, stratégie, prebiehajúce procesy na úrovni kognitívnych funkcií, prelínajúce sa štádiá, fázy či individuálne štýly rozhodovania. Snahu o progres môžeme vidiet' aj v konštruovaní nových diagnostických metód, v náraste počtu výskumných štúdií i v celkovom rozmachu problematiky kariérového poradenstva.

Pred druhou smerovou vol'bou stoja 18 - 19 roční adolescenti. S pribúdajúcimi rokmi rastie miera kryštalizácie identity a predpoklad adekvátneho rozhodovania. Medzi očakávaním a realitou však častokrát nedochádza k zhode. Ako uvádza Pilárik „takmer $44 \%$ žiakov v posledných dvoch rokoch stredoškolského štúdia pocit'uje výraznú nepripravenost' na realizáciu kariérového rozhodnutia“ (2019, s. 191). Podl'a Olssona, Bonda, Burnsa, Vella-Brodricka a Sawyera (2003) potrebujú mladí l'udia v tomto období získat' zdroje pre úspešné prispôsobenie sa a zvládanie podmienok neustále sa meniacej fyzickej, psychickej a sociálnej oblasti v období adolescencie. Ak sú dobre vybavení zdrojmi vo vnútri seba, v rodine a v sociálnej opore, je možné efektívnejšie vyrovnávanie sa $\mathrm{s}$ nepriazňou osudu.

V súvislosti s vnútornými zdrojmi osobnosti sa dostávame k pojmu reziliencia. Mastenová, Best, Garmezy (1990) definujú rezilienciu ako proces, schopnost' ako aj výsledok úspešnej adaptácie človeka navzdory nepriaznivým ako aj ohrozujúcim podmienkam, ktoré môžu súvisiet' tiež s fázou aktívneho rozhodovania o budúcej kariére mladého človeka. Preto považujeme za prínosoné preskúmat' vzt’ah dvoch zjavne úzko súvisiacich konceptov - t'ažkostí s kariérovým rozhodovaním 
a reziliencie. A to práve u študentov, ktorí sa nachádzajú pred uskutočnením druhej smerovej vol'by, ktorá znamená pre nich jednu z klúčových volieb na ich kariérovej ceste.

\section{1 Ťažkosti s kariérovým rozhodovaním študentov pred druhou smerovou vol'bou}

Obdobie adolescencie trvá od 15 - 20 rokov, je na začiatku plné rozporov, zmätku a kríz pri hl'adaní svojho miesta vo svete. Adolescent postupne prichádza na to, v ktorej oblasti je úspešný, čo mu neskôr pomáha pri predstavách o profesijnej budúcnosti Adolescent si značne uvedomuje svoju identitu a preberá zodpovednost' za svoje rozhodnutia. Dôležitým medzníkom je maturita, kedy zaznamenávame koniec jednej etapy preukázaním vedomostí a schopností a vol’ba povolania ako začiatok druhej etapy (Říčan, 2006).

Ťažkosti v procese kariérového rozhodovania Martincinová a Stead (2015, s. 4) považujú za „strešný pojem pre každého, kto má problémy s rozhodovaním, či už je to prechodný stav nerozhodnutosti alebo vzorec t’ažkostí vedúci k nerozhodnosti“. Jedným z hlavných ciel’ov kariérového poradenstva je ul'ahčit' proces rozhodovania o kariére klientom, a najmä v zmysle poskytnutia pomoci pri prekonávaní prekážok. Identifikácia jedinečných t’ažkostí, ktoré jednotlivcom bránia dosiahnut' rozhodnutie je nevyhnutným krokom pri poskytovaní odbornej pomoci, pretože bez zmapovania problému, nemožno dospiet' k jeho vyriešeniu (Gati, Krauzs, Osipow, 1996). Emocionálne a osobnostné faktory sú pri kariérovom rozhodovaní kl'účové, preto sa t’ažšie prekonávajú (Santos, 2001). Saka, Gati a Kelly (2008) sa zamerali na oblast' emocionálnych a osobnostných aspektov t'ažkostí $\mathrm{v}$ procese kariérového rozhodovania. Vypracovali taxonómiu, ktorá pomáha jednotlivcovi pri lokalizácii zdrojov jeho nerozhodnosti, a ktorá obsahuje tri hlavné oblasti t’ažkostí: Pesimistický pohl'ad, Úzkost' a Sebaobraz a identitu. Dimenzia Pesimistického pohl'adu je v taxonómii zmieňovaná ako tendencia človeka zameriavat' sa na negatívne aspekty situácií a očakávat’ negatívne výsledky. Špecificky identifikujú oblasti pesimistického pohl'adu na proces rozhodovania, na svet práce a na kotrolu jednotlivcom. Rôzne aspekty dimenzie Úzkosti sa spájajú s kariérovou nerozhodnost'ou a nerozhodnutost'ou a tiež s problémami, ktoré vyvstávajú počas rozhodovania (Fuqua, Seaworth, Newman, 1987; Kaplan, Brown, 1987; Santos, 2001). Saka a Gati (2008) rozlišujú úzkost' z procesu rozhodovania, z neistoty obsiahnutej vo vol'be, z procesu vol'by a ohl'adom výsledku rozhodovacieho procesu. Ťažkosti vo formovaní stabilnej, nezávislej osobnej a pracovnej identity a pozitívneho self-konceptu obsahuje dimenzia Sebaobraz a identita. Saka a Gati (2008) sem radia t’ažkosti so sebavedomím, konfliktnú vzt’ahovú väzbu (v zmysle miery závislosti na názoroch rodiny) a nevykryštalizovanú identitu.

\subsection{Reziliencia ako dôležitý osobnostný faktor vo fáze kariérového rozhodovania}

Podl'a Komárika, Jenčovej, Krajčovičovej, Lamošovej, Repčíka, Šandorovej a Hučekovej (2010) rezilienciu možno definovat' ako mnohosystémový jav, spôsobilost' nepodl'ahnút' nepriaznivému pôsobeniu prostredia. Reziliencia obsahuje komponenty, ktoré sú osobným talentom jednotlivca, a ktoré sa osobnou výbavou jednotlivca stávajú prostredníctvom pôsobenia výchovy a životných skúseností. Podl'a Šolcovej (2009) reziliencia predstavuje interakciu medzi rizikovými a protektívnymi zdrojmi a činitel'mi. Práve kvôli týmto dôvodom a funkciám reziliencie považujeme rezilienciu za klúčovú osobnostnú premennú. Jej protektívny faktor, ale aj faktor výzvy, ku ktorej nás nepriaznivé životné udalosti môžu nabádat', a tiež aj faktor vyrovnávania (Fergus, Zimmerman, 2005) sú smerodajné pri prekonávaní nepriaznivých udalostí v živote. Za takúto udalost' môžeme považovat' aj obdobie pred druhou kariérovou smerovou vol'bou.

Predchádzajúce desat'ročia nám priniesli odborné poznatky nazerajúce na rezilienciu ako na psychickú odolnost', pôsobiacu na úspešné alebo neúspešné zvládanie zát'ažových situácií (Olsson et al., 2003; Kebza, Šolcová, 2008; Paulík, 2010; Komárik et al., 2010; McMahon, 2015). Proces kariérového rozhodovania považujeme za zát’ažovú situáciu, ktorá si vyžaduje zapojenie rôznych síl osobnosti adolescenta (Gati, Krausz, Osipow, 1996; Saka, Gati, Kelly, 2008; Paulík, 2010; Gati, 
Gadassi, Saka, Hadadi, Ansenberg, Friedmann, Asulin-Peretz, 2011; Shin, Kelly, 2015). Preto ciel'om našej štúdie je zhodnotit' vzt’ah emocionálnych a osobnostných t’ažkostí s kariérovým rozhodovaním a reziliencie. Budeme tak predpokladat' významné negatívne vzt'ahy medzi rezilienciou a t’ažkost'ami s kariérovým rozhodovaním vo všetkých zložkách zmienenej taxonómie Sakaovej, Gatiho a Kellyho (2008). Predpoklady tak formulujeme na zákade vyššie spomenutých zdrojov (Fergus, Zimmerman, 2005; Šolcovej, 2009; Gati, Krausz, Osipow, 1996; Saka, Gati, Kelly, 2008; Paulík, 2010; Gati, Gadassi, Saka, Hadadi, Ansenberg, Friedmann, Asulin-Peretz, 2011; Shin, Kelly, 2015).

\section{METÓDY}

\subsection{Výskumný súbor}

Výskumný súbor tvorili študenti štvrtého ročníka štyroch gymnázií. Išlo o príležitostný výber. Štúdie sa zúčastnilo 111 respondentov, z toho z 47 (42,3\%) mužov a $64(57,7 \%)$ žien vo veku 18 $19 \operatorname{rokov}(\mathrm{M}=18,35 ; \mathrm{SD}=0,479)$.

\subsection{Meracie nástroje}

Dotazník The Emotional and Personality Career Difficulties scale (EPCD; Saka, Gati, Kelly, 2008) pozostáva z 53 položiek, pričom každá z nich reprezentuje jednu z troch skupín faktorov, ktoré vychádzajú z predchádzajúcich výskumov modelu emocionálnych a osobnostných aspektov t’ažkostí v kariérovom rozhodovaní a d’alej sa delia na 11 subškál: Pesimistický pohl'ad (pesimistický pohl'ad ohl'adom procesu rozhodovania, pesimistický pohl'ad na svet práce, pesimistický pohl'ad na kontrolu jednotlivcom); Úzkost' (úzkost' ohl'adom rozhodovacieho procesu, úzkost' z neistoty obsiahnutej vo vol'be, úzkost' z procesu vol'by, úzkost' ohl'adom výsledku rozhodovacieho procesu), Sebaobraz a identita (t’ažkosti so sebavedomím, všeobecnú úzkost', nevykryštalizovanú identitu a konfliktnú vzt’ahovú väzbu). Pre každú položku, participanti odpovedajú na 9 bodovej Likertovej škále od 1 - vôbec ma nevystihuje po 9 - vystihuje ma výborne. Pôvodná štúdia dokázala kroskulturálnu validitu, dobrú vnútornú konzistenciu a štruktúru meracieho nástroja prevedením konfirmačnej faktorovej analýzy (Saka ,Gati, Kelly, 2008).

Na zistenie miery reziliencie sme použili metodiku - Škála reziliencie (Wagnild, Young, 1993). Merací nástroj nám poskytol, do slovenčiny preložil a na našu populáciu dospievajúcich prispôsobil Emil Komárik. Škála reziliencie sleduje dva faktory, prvým je osobná kompetencia (sebestačnost', nezávislost', rozhodnost', nepremožitel'nost', kontrola, vynaliezavost', vytrvalost') a druhý faktor reprezentuje akceptáciu seba a života (adaptabilita, rovnováha, flexibilita, vyvážená predstava o živote). V našej štúdii sa však budeme zameriavat’ na globálnu rezilienciu, ktorá vzniká zlúčením týchto dvoch faktorov. Slovenský preklad zabezpečil Komárik a Jenčová. Škála reziliencie obsahuje 26 položiek, na ktoré participanti odpovedali na 7 - bodovej Likertovej škále, od 1 - vel’mi nesúhlasím po 7 - vel'mi súhlasím.

\subsection{Spracovanie dát}

Dáta sme spracovali štatistickým programom IBM SPSS Statistics 25. Na overenie našich hypotéz sme zvolili bivariačnú vzt’ahovú analýzu. Vzhl'adom na normálny tvar distribúcie hodnôt skúmaných premenných sme použili Pearsonov koeficient súčinovej korelácie. 


\section{VÝSLEDKY}

Výsledky uvádzame v nasledujúcich tabul'kách, ktoré popisujú vzt’ah jednotlivých t’ažkostí s kariérovým rozhodovaním a reziliencie. Prvá tabul'ka je zameraná na vzt'ah globálnych emocionálnych a osobnostných t’ažkostí s kariérovým rozhodovaním a reziliencie, nasledujúce tabul'ky sú radené na základe spomínaných troch dimenzií taxonómie Sakaovej, Gatiho a Kellyho (2008).

Tab 1 Vzt'ah emocionálnych a osobnostných t’ažkostí s kariérovým rozhodovaní a reziliencie $(n=111)$

$$
\begin{aligned}
& \text { Ťažkosti s kariérovým } \\
& \text { rozhodovaním } \\
& \text { (EPCD total) }
\end{aligned}
$$

\begin{tabular}{cl}
\multicolumn{2}{c}{ Reziliencia } \\
$\mathrm{r}$ & $\mathrm{p}$ \\
\hline $\mathbf{- 0 , 4 7 3}$ & $\mathbf{0 , 0 0 1}$
\end{tabular}

Legenda: $n$ - počet participantov, $r$ - Pearsonov korelačný koeficient, p-štatistická významnost', EPCD total- korelačná analýza prevedená so sumárnym skóre dotazníka EPCD

Predpokladaný vzt’ah emocionálnych a osobnostných t’ažkostí s kariérovým rozhodovaním (analýza zahŕňala sumárne skóre všetkých subškál dotazníka EPCD) sa potvrdil. Ide o štatisticky významný, stredne silný a negatívny vzt’ah.

Tab 2 Vzt'ah Pesimistického pohl'adu a reziliencie študentov pred druhou smerovou vol'bou $(n=111)$

\begin{tabular}{ccc}
\hline Pesimistický pohl'ad & \multicolumn{2}{c}{ Reziliencia } \\
\hline $\begin{array}{c}\text { PESIMISTICKÝ POHL'AD } \\
\text { proces }\end{array}$ & $\mathbf{p}$ \\
\hline $\begin{array}{c}\text { Pesimistický pohl'ad na rozhodovací } \\
\text { Pesimistický pohl'ad na svet práce }\end{array}$ & $\mathbf{- 0 , 2 3 8}$ & $\mathbf{0 , 0 0 9}$ \\
$\begin{array}{c}\text { Pesimistický pohl'ad na kontrolu } \\
\text { jednotlivcom }\end{array}$ & 0,064 & $\mathbf{0 , 0 1 2}$ \\
\hline
\end{tabular}

Legenda: $n$ - počet participantov, $r$ - Pearsonov korelačný koeficient, $p$ - štatistická významnost'

V prípade dimenzie Pesimistický pohl’ad sme zistili štatisticky významný negatívny slabý vztah $\mathrm{v}$ súvislosti s rezilienciou $\mathrm{u}$ študentov pred druhou smerovou vol'bou $(\mathrm{r}=-0,246 ; \mathrm{p}=$ 0,009). V prípade aspektov pesimistický pohl'ad na rozhodovací proces bol vzt'ah štatisticky významný, negatívny, avšak slabý $(\mathrm{r}=-0,238 ; \mathrm{p}=0,012)$. V prípade aspektu pesimistický pohl'ad na kontrolu jednotlivcom bol vzt’ah významný negatívny a stredne silný ( $r=-0,348 ; p=0,001)$. Čo sa týka pesimistického pohl'adu na svet práce, štatisticky významný vzt’ah sme nezistili. 
Tab 3 Vzt'ah Úzkosti a reziliencie študentov pred druhou smerovou vol'bou $(n=111)$

\begin{tabular}{ccc} 
Úzkost' & \multicolumn{2}{c}{ Reziliencia } \\
& r & $\mathrm{p}$ \\
\hline ÚzKoSŤ & $\mathbf{- 0 , 4 0 7}$ & $\mathbf{0 , 0 0 1}$ \\
Úzkost' z procesu rozhodovania & $\mathbf{- 0 , 2 6 8}$ & $\mathbf{0 , 0 0 4}$ \\
Úzkost' z neistoty obsiahnutej vo vol'be & $\mathbf{- 0 , 4 7 5}$ & $\mathbf{0 , 0 0 1}$ \\
Úzkost' z procesu vol'by & $\mathbf{- 0 , 3 3 5}$ & $\mathbf{0 , 0 0 1}$ \\
Úzkost' ohl'adom výsledku rozhodovacieho \\
procesu
\end{tabular}

Legenda: $n$ - počet participantov, $r$ - Pearsonov korelačný koeficient, $p$ - štatistická významnost'

Dimenzia Úzkost' a všetky jej aspekty štatisticky významne a negatívne korelovali s rezilienciou študentov pred druhou smerovou vol'bou. V prípade dimenzie Úzkosti bol vzt'ah stredne silný, podobne ako $v$ prípade úzkosti z neistoty obsiahnutej vo vol'be a úzkosti z procesu vol'by $(\mathrm{r}=-0,335$ $-r=-0,475 ; p=0,001)$. Slabšie negatívne, avšak štatisticky vznamné vzt'ahy sme zaznamenali $\mathrm{v}$ prípade úzkosti $\mathrm{z}$ procesu rozhodovania $(\mathrm{r}=-0,268 ; \mathrm{p}=0,001)$ a úzkosti ohl'adom výsledku rozhodovacieho procesu $(r=-0,272 ; p=0,004)$.

Tab 4 Vzt'ah t'ažkostí so sebaobrazom a identitou a reziliencie študentov pred druhou smerovou vol'bou $(n=111)$

Ťažkosti so sebaobrazom a identitou

Reziliencia r p

ŤAŽKOSTI SO SEBAOBRAZOM A IDENTITOU $-0,548$ 0,001

Úzkostlivost' $-0,411$ 0,001

Nízka sebaúcta $-0,511$ 0,001

Nevykryštalizovaná identita $-0,440$ 0,001 Konfliktná vzt’ahová väzba $-0,422$ 0,001

Legenda: $n$ - počet participantov, $r$ - Pearsonov korelačný koeficient, $p$ - štatistická významnost'

Dimenzia Sebaobraz a identita a všetky jej aspekty štatisticky významne negatívne a stredne silno korelovali s rezilienciou študentov pred druhou smerovou vol'bou. Najsilnejší negatívny štatisticky významný vzt’ah spomedzi dimenzií t’ažkostí bol zistený práve s dimenziou Sebaobraz a identita ( $\mathrm{r}$ $=-0,548 ; \mathrm{p}=0,001)$. V prípade jej jednotlivých aspektov boli vzt'ahy stredne silné a negatívne $(\mathrm{r}=$ $0,411-r=-0,511 ; p=0,001)$. 
Pomáhajúce profesie, roč. 3, č. 2, 2020, 23-32

\section{DISKUSIA}

Ciel'om predkladanej štúdie bolo skúmanie vzt’ahu medzi emocionálnymi a osobnostnými t’ažkost’ami s kariérovým rozhodovaním a rezilienciou študentov, ktorí sa nachádzajú pred druhou smerovou vol'bou. Pri identifikovaní spektra t’ažkostí sme sa opierali o taxonómiu Sakovej, Gatiho a Kellyho (2008). V nasledujúcom texte sa snažíme diskutovat' výsledky a zhodnotit' opodstatnenie sledovaných vzt'ahov. Vzt'ahy diskutujeme podl'a poradia uvádzaných výsledkov.

\subsection{Vzt’ah emocionálnych a osobnostných t’ažkostí s kariérovým rozhodovaním a reziliencie}

Naša prvá hypotéza overovala existenciu negatívneho vzt’ahu medzi konceptom reziliencie a globálnymi t’ažkost’ami s kariérovým rozhodovaním u stredoškolských študentov pred druhou smerovou vol'bou. Výsledky nám dovol'ujú konštatovat', že kariérové rozhodovanie sprevádzané t’ažkost'ami úzko súvisí s mierou reziliencie u jednotlivca. Naše výsledky zaznamenávaju stredne silný negatívny vzt’ah medzi sledovanými konceptami. Zistenia sú v súlade so štúdiou Shinovej a Kellyho (2015), ktorí zistili, že reziliencia je v procese kariérového rozhodovania spojená s nižším výskytom t'ažkostí. Podl'a Walda, Taylora, Asmundsona, Janga, a Stapletona (2006) sa reziliencia vzt'ahuje k pozitívnej adaptácii alebo schopnosti zachovat' si, či obnovit' duševné zdravie, a to napriek zažívaniu nepriaznivých okolností. Naše výsledky potvrdzujú fakt, že sa do okruhu nepriaznivých udalostí môžu zahrnút' aj udalosti spojené s uskutočňovaním kariérových volieb.

\subsubsection{Vzt'ah pesimistického pohl'adu a reziliencie}

Z našich zistení vyplýva negatívny, aj ked' slabý vzt’ah dimenzie Pesimistického pohl'adu a reziliencie. Je však otázne, ako na seba premenné pôsobia. Podl'a Gruhla a Körbächera (2013) pesimistický postoj človeka vplýva na prežívanie zát'ažových situácií i na samotnú rezilienciu. Teda reziliencia môže vystupovat' v úlohe ochranného faktora pred t'ažkost'ami, ale zároveň, vyššia miera pesimistického pohl'adu môže zas úroveň reziliencie oslabovat'. V každom prípade je vzt'ah slabý. Viac o dimenzii pesimistického pohl’adu nám napovedajú zistené vzt’ahy medzi jednotlivými aspektmi pesimistického pohl'adu (Tab2).

V prípade pesimistického pohl’adu na rozhodovací proces je vzt’ah negatívny, avšak slabý. Sakaová, Gati a Kelly (2008) pesimistický pohl'ad na proces rozhodovania charakterizovali nízkou sebaúčinnost'ou a vnímanou neschopnost'ou realizovat' kariérové rozhodnutie. Spojitost' sebaúčinnosti a reziliencie odráža presvedčenie o zvládnutí úloh a vynakladanie vlastného úsilia do ich riešenia (Kebza, Šolcová, 2008). V prípade pesimistického pohl'adu na kontrolu jednotlivcom sme zaznamenali stredne silný a negatívny vzt’ah s rezilienciou. Vysoká úroveň pesimistického pohl'adu na kotrolu je charakteristická pre menej aktívnych jednotlivcov s externou lokalizáciou kontroly (Saka, Gati, Kelly, 2008). Zároveň Rotterov koncept lokalizácie kontroly je súčast'ou teoretických koncepcií reziliencie (Kebza, Šolcová, 2008) a zohráva kl'účovú úlohu pri spôsobe zvládania zátažovej situácie. Pesimistický pohl'ad na svet práce sa podla našich výsledkov s rezilienciou významne nespája. Sústredenie sa na negatíva pracovného sveta vyzerá byt’ nezávislé od miery reziliencie. Pesimistický pohl'ad na svet práce ovplyvňujú skôr vonkajšie faktory ako nevýhody dynamických zmien na trhu, dostupné povolania a kurzy, pričom reziliencia vychádza z vnútorných zdrojov osobnosti (Olsson et al., 2003).

\subsubsection{Vzt'ah úzkosti a reziliencie}

$\mathrm{V}$ prípade dimenzie Úzkosti sme zistili negatívny a stredne silný vzt'ah s rezilienciou. Viac rezilientní jednotlivci sa lepšie adaptujú na zát’ažové situácie a ich miera úzkosti klesá (Hjemdal, Vogel, Solem, Hagen, \& Stiles, 2011; Anyan, Hjemdal, 2016). Pri úzkosti z procesu rozhodovania zaznamenávame slabý negatívny vzt’ah s rezilienciou. Tento aspekt je spájaný so stresom pred 
začiatkom výberu a s perfekcionizmom (Saka, Gati, Kelly, 2008). Gati a jeho kolegovia (2011) zistili, že vyššia miera perfekcionizmu predstavuje väčší výskyt t'ažkostí s kariérovým rozhodovaním. Sheppardová a Hicks (2017) spájali perfekcionizmus s rezilienciou, čím poskytli podporu pre naše zistenia.

Medzi rezilienciou a kategóriou úzkosti ohl'adom neistoty obsiahnutej vo vol'be pozorujeme štatisticky signifikantú negatívnu koreláciu. Môžeme sa nazdávat', že úzkost' prameniaca z nízkej tolerancie $\mathrm{k}$ nejednoznačnosti a nejasnosti komplikuje stredoškolským študentom kariérové rozhodovanie (Saka, Gati, Kelly, 2008), zatial' čo reziliencia, ktorá sa vyznačuje flexibilitou či akceptáciou stresovej situácie, tento proces ul'ahčuje (Kebza, Šolcová, 2015).

Saka, Gati a Kelly (2008) tretiu kategóriu, a to úzkost' z procesu vol'by charakterizujú strachom prameniacim z vol'by nesprávnej alternatívy i samotným perfekcionizmom pri výbere z možností. Reziliencia by mala v tomto kontexte spíňat' svoju protektívnu funkciu a znížit' tieto t'ažkosti. Naše výsledky tento predpoklad potvrdili, ked'že sme zistili negatívny a stredne silný vt’ah medzi rezlienciou a úzkost'ou z procesu vol'by.

Predpokladali sme tiež štatisticky významný a negatívny vzt’ah medzi rezilienciou a úzkost'ou ohl'adom výsledku rozhodovacieho procesu. Náš predpoklad potvrdili výsledky, avšak vzt’ah je z hl'adiska sily slabý. Vybraná kariérová možnost' nemusí naplnit' jednotlivcove očakávania, čo vyvoláva pocity úzkosti (Saka, Gati, Kelly, 2008). Ked'že vyššia miera úzkosti prevláda u menej rezilientných osôb (Hjemdal et al., 2011; Anyan, Hjemdal, 2016), inak to pravdepodobne nebude ani v prípade obáv ohl'adne výsledku kariérového rozhodovania.

\subsubsection{Vzt'ah sebaobrazu, identity a reziliencie}

Osobnost' je s konceptom reziliencie úzko spätá. Podl’a Olssona et al. (2003) osobnostné faktory ako sebavedomie, sebaúčinnost', hodnoty a iné, ovplyvňujú mieru prítomnej reziliencie. Toto tvrdenie platí aj pre naše výsledky, ked’že dimenzia Sebaobraz a identita, a tiež všetky jej aspekty stredne silno negatívne korelujú s protektívnym osobnostným faktorom reziliencie. Zároveň zistenia poukazujú na najsilnejší vzt'ah práve tejto dimenzie s rezilienciou spomedzi všetkých dimenzií t’ažkostí s kariérovým rozhodovaním. V nasledujúcej úvahe uvedieme jednotlivé aspekty Sebaobrazu a identity vo vzt’ahu k reziliencii.

Úzkostlivost' je hodnotená ako neadaptívna súčast’ osobnosti, ktorá brzdí bezproblémový priebeh kariérového rozhodovania. Reziliencia naopak tento proces dopíňa ako jeho pozitívna súčast' (Shin, Kelly, 2015). Sebavedomie, a teda opak nízkej sebaúcty môže vstupovat’ ako faktor reziliencie u adolescenta, v rámci jeho sebahodnotenia (Kebza, Šolcová, 2008). Môžeme sa domnievat', že na problémy s uvedomením si vlastných hodnôt vplýva faktor vyššej či nižšej reziliencie osobnosti. Naše zistenia podporuje Paulík (2010), ktorý hovorí, že reziliencia sa v období adolescencie podiel'a na prekonávaní vnútorného chaosu plynúceho z formovania identity, čo zodpovedá práve aspektu nevykryštalizovanej identity. V prípade aspektu konfliktnej vzt'ahovej väzby berieme do úvahy vplyv iných l'udí na rozhodovanie, ktorý sledovalo viacero štúdií prinášajúc rozporuplné výsledky. Zapájanie iných l'udí do kariérového rozhodovania na žiaka môže vplývat' negatívne (Gati, Saka, 2001; Hroncová, Balážová, Sollár, 2017), jeho reziliencia je nižšia, vyhl'adáva pomoc od autority alebo sa riešeniu vyhýba (Komárik, Krajčovičová, 2010). V našich výsledkoch sme zistili negatívnu súvislost' t'ažkostí s konfliktonou vzt'ahovou väzbou a rezilienciou. Zapájanie druhých l'udí do rozhodovania, a navyše konfliktným spôsobom môže mat' za následok zníženie reziliencie alebo aj naopak, nízka reziliencia môže vzbudzovat' konfikty vo vzt'ahoch s najbližšími.

\subsection{Limity štúdie a odporúčania pre d'alší výskum}

Pri realizovaní našej štúdie si uvedomujeme limity, ktoré by sme radi predstavili. Rozdiely v meranej reziliencii mohli byt' zapríčinené individuálne prežívanými zát’ažovými udalost'ami jednotlivých žiakov. V období zberu dát sa mohol každý žiak nachádzat' v inej životnej situácií 
(rozvod rodičov, smrt' blízkej osoby, zdravotné problémy a pod.), subjektívne prežívané faktory mohli následne ovplyvnit' výsledky meranej reziliencie a taktiež výskyt t'ažkostí v rozhodovaní o kariére. V januári sa študenti 4. ročníkov gymnázií intenzívne pripravovali na písomnú maturitnú skúšku, ktorá je často sprevádzaná pocitmi stresu či úzkosti, čo mohlo ovplyvnit’ psychickú pohodu participantov, a najmä výsledky v aspekte Úzkost'. Čo sa týka výskumného súboru, ženy tvorili väčšiu čast' našich participantov. Generalizovat’ výsledky nášho výskumu na celú populáciu tiež nie je možné, pretože našu vzorku tvorili výhradne študenti navštevujúci 4. ročník dvoch gymnázií na strednom Slovensku.

Pre d’alší výskum v danej problematike navrhujeme, aby boli t’ažkosti s kariérovým rozhodovaním zist'ované pomocou meracieho nástroja, ktorý meria t’ažkosti vo všeobecnosti, nielen ich emočné a osobnostné aspekty - takým meracím nástrojom je napríklad Specialty Indecision Scale (Richard, Savickas, Calli, Englert, \& Bono, J, 2007). Ďalej odporúčame rozšírit’ výskumnú vzorku z hl'adiska počtu a skúmat’ naše premenné aj na inej populácii, napr. u vysokoškolských študentov.

\section{ZÁVER}

V predkladanej štúdii sme sledovali vzt'ah reziliencie a t’ažkostí s kariérovým rozhodovaním študentov pred uskutočnením druhej kariérovej smerovej vol'by. V prípade t’ažkostí s rozhodovaním sme vychádali z taxonómie Sakaovej, Gatiho a Kellyho (2008). Výsledky korelačnej analýzy potvrdili naše predpoklady, ktoré nám dovol'ujú konštatovat', že emocionálne a osobnostné t’ažkosti s kariérovým rozhodovaním môžu byt' viac objasnené aj z pohl'adu osobnostných faktorov, medzi ktoré radíme aj protektívny faktor reziliencie. Významnost' vzt'ahu medzi emocionálnymi a osobnostnými t’ažkost’ami s kariérovým rozhodovaním a rezilienciou sa preukázala vo všetkých troch dimenziách t’ažkostí a ich kategóriách. Výnimkou bola kategória pesimistický pohl'ad na svet práce, ktorá sa vo vzt’ahu s rezilienciou preukázala ako štatisticky nevýznamná. V prípade dimenzie Sebaobraz a identita sa vzt'ah s rezilienciou preukázal ako najsilnejší. Výsledky štúdie nabádajú k rozsiahlejšiemu skúmaniu témy t'ažkostí s rozhodovaním a poukazujú na nezanedbatel'né zistenia, ktoré môžu byt' d'alej prospešné v oblasti výskumu kariérového poradenstva.

\section{LITERATÚRA}

Anyan, F., \& Hjemdal, O. (2016). Adolescent stress and symptoms of anxiety and depression: Resilience explains and differentiates the relationships. Journal of affective disorders, 203, 213-220.

Fergus, S., \& Zimmerman, M. A. (2005). Adolescent resilience: A framework for understanding healthy development in the face of risk. Annu. Rev. Public Health, 26, 399-419.

Fuqua, D. R., Seaworth, T. B., \& Newman, J. L. (1987). The relationship of career indecision and anxiety: A multivariate examination. Journal of Vocational Behavior, 30(2), 175-186.

Gati, I., \& Saka, N. (2001). High school students' career-related decision-making difficulties. Journal of Counseling \& Development, 79(3), 331-340.

Gati, I., Gadassi, R., Saka, N., Hadadi, Y., Ansenberg, N., Friedmann, R., \& Asulin-Peretz, L. (2011). Emotional and personality-related aspects of career decision-making difficulties: Facets of career indecisiveness. Journal of Career Assessment, 19(1), 3-20.

Gati, I., Krausz, M., \& Osipow, S. H. (1996). A taxonomy of difficulties in career decision making. Journal of counseling psychology, 43(4), 510.

Gruhl, M., \& Körbächer, H. (2013). Psychická odolnost v každodenním životě. Portál. 
Hjemdal, O., Vogel, P. A., Solem, S., Hagen, K., \& Stiles, T. C. (2011). The relationship between resilience and levels of anxiety, depression, and obsessive-compulsive symptoms in adolescents. Clinical psychology \& psychotherapy, 18(4), 314-321.

Hroncová, K., Balážová, M., \& Sollár, T. (2017). Vzt’ahová väzba k rodičom ako prediktor t’ažkostí v kariérovom rozhodovaní adolescentov. In Conference: Phd existence 2017 : Psychologie v době internetu ( s. 303-312). Olomouc : Univerzita Palackého.

Kaplan, D. M., \& Brown, D. (1987). The role of anxiety in career indecisiveness. The Career Development Quarterly.

Kebza, V., \& Solcová, I. (2015). RESILIENCE: NEKTERÉ NOVEJSÍ KONCEPCE PSYCHICKÉ ODOLNOSTI/Resilience: some incoming conceptions of psychological resistance. Ceskoslovenska Psychologie, 59(5), 444.

Kebza, V., \& Šolcová, I. (2008). Hlavní koncepce psychické odolnosti. Československá psychologie, 52(1), 1.

Komárik, E. Jenčová, A., Krajčovičová, K., Lamošová, J., Repčík, R., Šandorová, D., \& Hučeková, D. (2010). Kontexty reziliencie. Nitra, Slovakia: UKF, Pedagogická fakulta.

Komárik, E., Jenčová, A., Krajčovičová, K., Lamošová, J., Repčík, R., Šandorová, D., \& Hučeková, D. (2010). Kontexty reziliencie. Nitra: PF UKF.

Martincin, K. M., \& Stead, G. B. (2015). Five-Factor Model and Difficulties in Career Decision Making: A Meta-Analysis. Journal of Career Assessment, 23(1), 3-18.

Masten, A. S., Best, K. M., \& Garmezy, N. (1990). Resilience and development: Contributions from the study of children who overcome adversity. Development and psychopathology, 2(4), 425-444.

McMahon, B. (2015). Seeing Strengths in a Rural School: Educators' Conceptions of Individual and Environmental Resilience Factors. Journal for Critical Education Policy Studies (JCEPS), 13(1).

Olsson, C. A., Bond, L., Burns, J. M., Vella-Brodrick, D. A., \& Sawyer, S. M. (2003). Adolescent resilience: A concept analysis. Journal of adolescence, 26(1), 1-11.

Paulík, K. (2010). Psychologie lidské odolnosti. Grada Publishing as.

Pilárik, L. (2019). Kariérové rozhodovanie adolescentov : Osobnostné a emočné aspekty t’ažkostí a stratégií kariérového rozhodovania. Nitra : Univerzita Konštantína Filozofa.

Richard V.G., Savickas, M., Calli, J., Englert, A, \& Bono, J. (2007). Manual for the Specialty Indecision Scale, 2nd Edition. Wahington, D.C: Association of American Medical Colleges.

Říčan, P. (2006). Cesta životem. Praha: Portál. 2006.

Saka, N., Gati, I., \& Kelly, K. R. (2008). Emotional and Personality - Related Aspects of Career Decision Making Difficulties. Journal of Career Assessment, 16(4), 403-424.

Santos, P. J. (2001). Predictors of generalized indecision among Portuguese secondary school students. Journal of Career Assessment, 9, 381-396.

Sheppard, L., \& Hicks, R.E. (2017). Maladaptive perfectionism and psychological distress. In International Journal of Psychological Studies. 2017, 9(4), 65-75.

Shin, Y. J., \& Kelly, K. R. (2015). Resilience and decision-making strategies as predictors of career decision difficulties. The Career Development Quarterly, 63(4), 291-305. 
Šolcová, I. (2009). Rozvoj rezilience v detství a dospělosti. Praha, Czech republic: Grada.

Wagnild, G. M., \& Young, H. M. (1993). Development and psychometric. Journal of nursing measurement, 1(2), 165-17847.

Wald, J., Taylor, S., Asmundson, G. J., Jang, K. L., \& Stapleton, J. (2006). Literature review of concepts: Psychological resiliency (No. DRDC-CR-2006-073). BRITISH COLUMBIA UNIV VANCOUVER.

\title{
RESILIENENCE AND CAREER DECISION-MAKING DIFFICULTIES OF STUDENTS BEFORE SECOND CAREER CHOICE
}

\begin{abstract}
The aim of the paper was to identify a relation between resilience and career decision-making difficulties in secondary school students. Our research sample consisted of 111 participants (47 men, 64 women) who were 4 th graders in the age of 18-19 from two high schools. The degree of resilience was examined via the Resilience Scale (Wagnild, Young, 1993) and for the identification of career decisionmaking difficulties the EPCD questionnaire (Emotional and Personality Career Difficulties Scale), by Israeli authors Saka, Gati and Kelly (2008), was used. The results revealed statistically significant negative relation between resilience and career decision-making difficulties. Resilience correlated negatively with all three dimensions of career decision-making - Pessimistic views, Anxiety, Self and identity. The findings can be useful for further research in the field of career counselling.
\end{abstract}

Kl'účové slová: resiliencie, career decision-making difficulties, secondary school students, the second career choice

Grantová podpora:

Príspevok vznikol ako súčast' riešenia grantového projektu UGA IX/1/2019 Faktory efektívneho rozhodovania študentov podl'a Teórie kognitívneho spracovania informácií v oblasti kariérového poradenstva. 